\title{
The Development of Higher Order Thinking Laboratory to Improve Transferable Skills of Students
}

\author{
A.Malik ${ }^{1}$, A. Setiawan ${ }^{2}$ \\ ${ }^{1}$ School of Postgraduate Studies \\ ${ }^{2}$ Faculty of Technical and Vocational Education \\ Universitas Pendidikan Indonesia \\ Bandung, Indonesia \\ adamupi14@gmail.com
}

\begin{abstract}
The Physics Education Program course on Basic Physics course showed that most students are still not able to develop higher order thinking skills when doing the practical implementation. Their main activities are still limited to practice low-level of thinking skills. To increase the transferable skills of students, higher order thinking laboratory practicum is applied in this study. The purpose of this research is to develop practical models that can increase the transferable skills of students. The methodology used in this study is qualitative Research. The research was conducted at the Physics Education program. The population research is physics education students class 2014. The method used to collect data is random sampling in which the chosen class is class $A$. The data regarding the practical implementation of the students is collected through observations and interviews. The observation results show the practical implementation models used in the form of verification lab to train basic level thinking skills, and the interviews show that thinking skills trained during the lab practices are still a basic level. Thus, the need to develop practical models that can increase the transferable skills of students, so that they can be applied in daily life according to the demands of the National Qualifications Framework of Indonesia and the demand from the working world.
\end{abstract} skills

Keywords-higher order thinking laboratory, transferable

\section{INTRODUCTION}

Higher education should consider few things related to preparing its students in facing the internal and external challenges. This consideration is also in line with the reasoning of the change in curriculum 2013. The internal challenge is the demand to fit the eight national education standards. The external challenge is the globalization with the implementation of ASEAN Community, CAFTA, APEC, WTO; environmental issues; the ICT development; the convergence of science and technology; science-based economy; the rise of creative economy and culture; the shifting of world economic power; the influence and the effect of technoscience; quality, investigation, and transformation of education sector. Another external challenge is the graduate will be demanded to have clear and critical thinking; to analyze the moral of a problem; to be a responsible citizen; to understand and be tolerable to different views; to be able to live in a global society; to have an open mind; to prepare for work; to have intelligence according to his interest; to be responsible to his neighborhood.

All these things above is in line with the demand of learning objectives expected from the implementation of National Qualification Framework of Indonesia (KKNI) in the knowledge aspects, attitudes, and the specially skilled works. Thus, higher education should prepare its students with various skills to face the challenges above and to face the $21^{\text {st }}$ century. One of the skills needed to be trained and developed regarding competition in the $21^{\text {st }}$ century is transferrable skills.

Transferable skills can be defined as the skills developed in a situation that can be transferred to other situations [1,2]. There are differences in the conceptual understanding of transferable skills in different countries, but in general, transferable skills refers to some important competencies that can be learned. Everyone needs to master it, should he wants to have a chance of success, be a leader and be productive in his life.

Several studies that explained the need to developed transferable skills students have been carried out $[3,4,5,6,7,8]$. Transferable skills in this study were developed through a practical model of higher order thinking laboratory (HOT Lab). HOT Lab practicum models developed refers to a combination of learning models Creative Problem Solving (CPS) and the Model of Problem Solving Laboratory (PSL).

\section{THEORETICAL FRAMEWORK}

\section{A. Transferable Skills}

Some terms that refer to the transferable skills that are used in various countries including life-oriented, work-oriented, life skills, 21st-century skills, global competence, soft skills, crosscutting skills, generic skills, transversal skills, non-cognitive skills, cross-curricula skills, employability skills, core skills, key skills. There are differences and conceptual understanding of transferable skills in different countries but in general, transferable skills refers to some important competencies that can be learned and needed by everyone to have a chance of success, become leaders and productive in his life.

Transferable skills are essential to be trained and developed by the students considering some of the following points: the 
effectiveness of higher education is being assessed to the extent to which students acquire the skills they need to work [9]; universities around the world are expected to produce graduates who have the skills that are capable of responding to the needs of the ever-changing and complex environment at the workplace [10]; the employers now expect higher education institutions to inculcate generic skills or comprehensive work skills into the curriculum; the points above increase the need for graduates to be aware of the skills they develop during higher education time and should be given the opportunity to develop these skills further [11]; increased emphasis is being promoted by the education in various countries [12,13] and international level [14].

According to James and Margaret [15], some frameworks of transferable skills that have been developed include: OECD (2009); Association for Career and Technical Education (2010); Bedwell, W.L., Salas, E., and Fiore, B.C. (2011); Binkley, M, et al. (2010); Finegold, D., and Notabartolo, U.S. (2010); Conley, D.T. (2007); Hoyle, R.H., and Davisson, E.K. (2011); Voogt, J., and Pareja Roblin, N. (2010).

In addition to transferable skills framework mentioned above, there is other transferable skill framework raised by Binkley, et al. [16] which is used as a framework for research. This transferable skill framework has developed ten skills that are grouped into four categories, namely: ways of thinking that consist of creativity and innovation, critical thinking, problemsolving, decision making, learning to learn, metacognition; ways of working which include communication, collaboration (cooperation); tools for work consisting of information literacy and ICT literacy; living in the world covering local and global citizenship, life and career, personal and social responsibility including cultural awareness and competition. All the ten transferable skills developed in three categories in the KSAVE model (Knowledge, Skills, Attitudes, Values, and Ethics) [16]. The aspects developed in transferable skills are limited to five aspects. These aspects are creative thinking skills, critical thinking skills, problem-solving skills, communication skills, academic writing skill, and cooperation skill.

\section{B. Higher Order Thinking Laboratory (HOT Lab)}

Practicum is a set of activities that take place in the laboratory. These practices include demonstrations, computer simulations that are complement to experimental work on hand, offering students a rich learning experience, to gain a conceptual understanding of disciplines and develop practical skills [17,18]. Contributions in instructional science lab activities should be able to cultivate the ability in the development of conceptual thinking, evokes the imagination, stimulate the desire and methodological sharpness honed as part of the experimental experience. Practicum has been seen to have an important role in science at school. In particular, it has been claimed that the lab has an important role in determining the students' attitudes toward science at school and science outside the classroom [19]. It was also reinforced by the statement Zezekwa [20] the development of a positive attitude is one of the basic determinants of performance in every discipline of study. Also, the practicum can train and develop both soft skills and hard skills. Therefore, a practicum model that can develop both skills needs to be developed.
Higher Order Thinking Practicum Laboratory (HOT Lab) is inspired by Brookhart [21] who developed a particular strategy to assess strategic thinking like how well a student performs a task by asking students to perform tasks that must be completed and provide a variety of tasks. HOT Lab Practicum developed refers to a combination of learning models Creative Problem Solving (CPS) and the Model of Problem Solving Laboratory (PSL). CPS learning model centers on students' problem-solving skills, which emphasize balance divergent thinking (creative) and convergent thinking (critical) in every problem-solving steps [22]. Problem-solving learning model Laboratory (PSL) is a learning model that gives problems in the classroom, and the problem-solving techniques performed by laboratory activities. Once the issue is resolved through laboratory activities, students perform in class discussion to convey concepts that have been found [23].

PSL learning model that will be used is based on a model developed by Heller \& Heller [24]. HOT Lab Model consists of eight stages which are a mix between Creative Problem Solving (CPS) with Problem Solving Laboratory (PSL). HOT lab model stages can be seen in Table 1. The table will describe processes, stages, and thinking skills that are developed. Developed thinking skills include the ability of divergent as well as logical and critical thinking skill.

TABLE I. STAGES LABORATORY MODEL OF HIGHER ORDER THINKING

\begin{tabular}{|c|c|c|c|}
\hline Process & Stage & $\begin{array}{c}\text { The ability of } \\
\text { divergent }\end{array}$ & $\begin{array}{c}\text { Logical and } \\
\text { critical abilities }\end{array}$ \\
\hline \multirow[t]{3}{*}{$\begin{array}{l}\text { Understand } \\
\text { ing the } \\
\text { challenges }\end{array}$} & $\begin{array}{l}\text { The first stage: } \\
\text { Composing } \\
\text { opportunities }\end{array}$ & $\begin{array}{l}\text { Find } \\
\text { experiences, } \\
\text { roles, and } \\
\text { contexts to find } \\
\text { the object of } \\
\text { interest; } \\
\text { To explore the } \\
\text { openness of the } \\
\text { experience and } \\
\text { opportunities }\end{array}$ & $\begin{array}{l}\text { Accept the } \\
\text { challenge and start } \\
\text { systematic efforts } \\
\text { to respond to the } \\
\text { challenge }\end{array}$ \\
\hline & $\begin{array}{l}\text { The second } \\
\text { stage: } \\
\text { Exploring the } \\
\text { data }\end{array}$ & $\begin{array}{l}\text { Gather the facts } \\
\text { and investigate } \\
\text { the context of a } \\
\text { variety of } \\
\text { perspectives; } \\
\text { gather } \\
\text { information, } \\
\text { impressions, } \\
\text { and emotions }\end{array}$ & $\begin{array}{l}\text { Confirm the most } \\
\text { important facts } \\
\text { and analyze them }\end{array}$ \\
\hline & $\begin{array}{l}\text { The third stage: } \\
\text { Composing the } \\
\text { structure of the } \\
\text { problem }\end{array}$ & $\begin{array}{lr}\text { formulate } & \text { a } \\
\text { statement } & \text { of } \\
\text { problem } & \text { and } \\
\text { subproblem } & \text { as } \\
\text { much } & \text { as } \\
\text { possible } & \\
\end{array}$ & $\begin{array}{l}\text { Choose or prepare } \\
\text { a realistic problem } \\
\text { statement }\end{array}$ \\
\hline $\begin{array}{l}\text { Generating } \\
\text { ideas }\end{array}$ & $\begin{array}{l}\text { The fourth } \\
\text { stage: } \\
\text { Generating } \\
\text { ideas }\end{array}$ & $\begin{array}{l}\text { Register a lot of } \\
\text { alternatives and } \\
\text { possibilities for } \\
\text { the problem } \\
\text { statement }\end{array}$ & $\begin{array}{l}\text { Choose the most } \\
\text { useful and } \\
\text { interesting ideas }\end{array}$ \\
\hline $\begin{array}{l}\text { Preparation } \\
\text { for lab } \\
\text { work }\end{array}$ & $\begin{array}{l}\text { The fifth stage: } \\
\text { Developing } \\
\text { solutions }\end{array}$ & $\begin{array}{l}\text { Reaffirm ideas } \\
\text { and generate a } \\
\text { lot of evaluation } \\
\text { criteria as much } \\
\text { as possible }\end{array}$ & $\begin{array}{l}\text { Choose the } \\
\text { important criteria } \\
\text { for evaluating } \\
\text { ideas and then } \\
\text { using the criteria } \\
\text { to evaluate, } \\
\text { strengthen and } \\
\text { improve ideas }\end{array}$ \\
\hline
\end{tabular}




\begin{tabular}{|c|c|c|c|}
\hline Process & Stage & $\begin{array}{c}\text { The ability of } \\
\text { divergent }\end{array}$ & $\begin{array}{c}\text { Logical and } \\
\text { critical abilities }\end{array}$ \\
\hline & $\begin{array}{l}\text { The sixth stage: } \\
\text { Establishing the } \\
\text { base for } \\
\text { acceptance }\end{array}$ & $\begin{array}{l}\text { Consider the } \\
\text { potential and } \\
\text { objective } \\
\text { agreement to } \\
\text { the solution; } \\
\text { confirm } \\
\text { potential action } \\
\text { steps }\end{array}$ & $\begin{array}{l}\text { Focus on the most } \\
\text { realistic solution } \\
\text { then prepare to } \\
\text { follow up such } \\
\text { solutions; form } \\
\text { specific plans to } \\
\text { run the solution }\end{array}$ \\
\hline $\begin{array}{l}\text { Doing lab } \\
\text { work }\end{array}$ & $\begin{array}{l}\text { The seventh } \\
\text { stage } \\
\text { Doing lab work }\end{array}$ & $\begin{array}{l}\text { Work faster and } \\
\text { do more than } \\
\text { others; } \\
\text { provide a } \\
\text { variety of } \\
\text { interpretations, } \\
\text { apply a concept } \\
\text { in different } \\
\text { ways }\end{array}$ & $\begin{array}{l}\text { Competent use of } \\
\text { technology; } \\
\text { application of the } \\
\text { principles; } \\
\text { complete the } \\
\text { criteria to make } \\
\text { the solution }\end{array}$ \\
\hline $\begin{array}{l}\text { Communic } \\
\text { ating and } \\
\text { evaluating } \\
\text { results }\end{array}$ & $\begin{array}{l}\text { The eighth stage } \\
\text { Communicating } \\
\text { and evaluating } \\
\text { results }\end{array}$ & $\begin{array}{l}\text { Discussing a } \\
\text { situation always } \\
\text { has different } \\
\text { positions to } \\
\text { solve them; } \\
\text { develop or } \\
\text { enrich the ideas } \\
\text { of others; } \\
\text { analyzing a } \\
\text { problem or } \\
\text { problem solving } \\
\text { critically }\end{array}$ & $\begin{array}{l}\text { Present the } \\
\text { opinion of both } \\
\text { oral and written; } \\
\text { Develop and } \\
\text { respond to wrong } \\
\text { concepts; } \\
\text { make } \\
\text { generalizations; } \\
\text { make conclusions }\end{array}$ \\
\hline
\end{tabular}

\section{RESEARCH METHODOLOGY}

The population in this study is a Physics Education class of 2014 students who take the Basic Physics class. The subjects of this study consisted of two classes randomly selected to determine the class as a sample, and class A with forty students was selected as the sample.

The data were obtained using observation sheet. It was used to observe the implementation of the applied practicum model, and to guide the interview for the class lecturers and the students. The interview intended to ask the opinion of both the students and the lecturers regarding the effectiveness of the practicum model that was used. The implementation of the practicum was observed by an observer to be analyzed. Every step in the practicum and the interview results were described qualitatively.

\section{RESULT AND DISCUSSION}

\section{A. Result}

Based on observations about the implementation of the models, the following results were obtained. According to the analysis of syllabus and the SAP of the class lecturers, the higher order of thinking and scientific attitude were not explicitly apparent. Even if there is some evidence of them, it tends to be a random occurrence. It was found in the practicum activities that higher order thinking skill was not developed yet, and the scientific attitudes were not yet trained. The students were merely trained the scientific process.

One of the evidence in the analysis is that the students had no confidence to do the practicum activities independently, and the activities were only testing the existing theory in the reference list. They relied too much on the laboratory assistants to ask for help in doing practicum activities and the type of the practicum activities usually done were only verification type. Group activities that were done could ease the problem solving in the practicum. The availability of tools, supplies and equipment for the practicum need to be completed. The laboratory facility like chairs and tools and equipment containers needs more addition.

Based on interviews with the lecturer of the Basics Physics course, it is concluded that it is needed to develop a model of practicum that not only develops a low-level thinking skill, but also can train and develop higher level thinking skills and transferable skills as preparation for students to be able to apply it in daily life -day.

The result of the interview with the students taking Basic Physics course concludes that the problem that need to be solved in the practicum should be recent, and applicable. The method questions need to be systematic so that the student can experiment in the right way. The writing of the statement and diction in the module need to be clearer so that no misinterpretation will occur. The difficulty level of the questions in every module needs to be proportional. The practicum report should be returned to the student on time according to the schedule. The last, the group activities can make the problem solving easier.

Research findings indicate a need to develop practical models that can train and develop higher-order thinking skills that can eventually master the transferable skills. This skill will be able to be applied in various fields of life as preparation for students to live in the community.

The result of observing the implementation of practicum model and the interviews shows the consistent findings that the current practicum is only to train and develop a lower level of thinking skill. The students demand the renewal and innovation in the implementing the practicum activities. It should not only to verify the existing theory but also the type of activities that can train and develop the transferrable skills as the society and the working world demand.

\section{B. Discussion}

Based on the observation of the implementation of practicum model that was used and the result of the interviews as well as the previous experience, Higher Order Thinking Laboratory model (HOT Lab) is then developed. This model is designed based on the experience and learning from the practicum implementation that intends to verify the existing theory for the past four years (2011-2014). HOT lab emphasizes the renewal, innovation, and opportunity for the students to increase their competencies (cognitive, attitude, and skills). It is designed to increase the access of high quality higher education. It is also hoped that this program will equip the students, the future teachers, with the ability to compose, design, and implement this practicum model when they teach.

Higher Order Thinking Laboratory (HOT Lab) is a model of practicum that is given to student teachers organized physics of Physics Education Program and Teacher Training Faculty of Tarbiyah State Islamic University of Sunan Gunung Djati. This 
practicum model provided the knowledge and skills to students to improve practical skills in implementing, improving scientific attitude, and increase high-level thinking skills that include problem-solving skills, critical thinking skills, and creative thinking skills.

Students can implement more attractive and practical activities to train not only the cognitive aspects but also the scientific skills and attitudes. The essence of the model of this lab is to enable the students how to do a practicum. They begin with understanding the phenomena that occur in daily life, by doing lab work involving high-level thinking skills, then write and present the results of their practicum. During the practicum, students are also expected to build their scientific attitude. After carrying out all the practicum activities, students will be given a project to create a practical tool and evaluate his work.

The Application of Higher Order Thinking Laboratory (HOT Lab) in Physics Education Program is in line with the demands of learning achievement expected from the implementation of the Indonesian National Qualifications Framework (KKNI) in the aspect of knowledge, attitudes and values, and specific job skills [25]. Learning outcomes according to KKNI demands in the aspects of knowledge include: mastering basic concepts about education that includes the development of learners, learning theories, the nature of science and scientific thinking; mastering innovative teaching methods oriented personal skills, social and academic (life skills) in the teaching of physics; master the principles of physics-based instructional media development of science, technology contextually, especially Information and Communication Technology (ICT), and the surrounding environment; control of the management of resources in the implementation of the class, physics laboratories and educational institutions and master the concepts of physics based on natural phenomena which support the learning of physics at school.

Learning outcomes in attitude and values aspects include: moral, ethics, work ethic, and a high responsibility for the task as well as proud to be a physics teacher candidates; openminded, critical, innovative, creative and confident in carrying out his duties as a teacher of physics; work together and have a social sensitivity and a high awareness of the public and the environment.

Learning outcomes in specific aspects of job skills include: planning, implementing, and evaluating learning physics is based in learning activities to develop the ability to think in accordance with the characteristics of the material physics, and scientific attitude according to the characteristics of students in curricular learning, curricular and extra-curricular activities by utilizing a variety of sources learning based on science, technology and the contextual environment; reviewing and implementing innovative learning methods that have been tested; manage resources and activities including managing the classroom, physics laboratories and educational institutions in a comprehensive manner; take strategic decisions based on the study of the problems of quality, relevance and access in the field of education in the administration of the class, physics laboratories and educational institutions which is its responsibility

\section{CONCLUSION}

Research findings indicate a need to develop practical models that can train and develop higher-order thinking skills that can eventually master the transferable skills. The students demand the renewal and innovation in the implementing the practicum activities. It should not only to verify the existing theory but also the type of activities that can train and develop the transferrable skills as the society and the working world demand.

\section{ACKNOWLEDGMENT}

The author would like to thank the lecturers Basic Physics course and the students who have participated in this study. Special thanks are also to the chairperson of the department of physical education and head of the Laboratory, who has helped and given permission to do the study.

\section{REFERENCES}

[1] Balcar J, Blažíčková J, Braňka J, Czesaná V, Gavenda M, Grygerová, Š Havlena J, Havlíčková V, Hladká M, Homolová E, Janoš J, Karásek Z, Karásková J, Kavan L, Kotíková J, Larsen C, Micková E, Rand S, Schmid A, Soukup T, Suciu D, Trokanová K, Vondráková M, Vychová H, Zacharová L, Transferability of Skills Across Economic Sectors: Role and Importance for Employment at European Level. Luxembourg: Publications Office of the European Union, 2011.

[2] Denicolo \& Reeves 2013 what are transferable skills and why they are needed? Retrieved June 21, 2015, from http://www.sagepub.com/upmdata/58777_Denicolo_\&_Reeves. pdf.

[3] Assiter, A, Transferable Skills in Higher Education. London: Kogan Page, 1995.

[4] BECTA, Multimedia Portables for Teachers: Evaluation Summary. London: British Educational Communications and Technology Agency, 2002.

[5] Centre for Staff and Educational Development (CSED), Computer and Information Technology Skills: Developing Staff Computer and Information Capability in Higher Education. Norwich: JISC/University of East Anglia, 2000

[6] CVCP, Skills Development in Higher Education: Full Report. London: The Committee of Vice-Chancellors and Principals of the Universities of the UK, 1998.

[7] Dearing, R, The Executive Summary: Higher Education in the Learning Society. London: The National Committee of Inquiry into Higher Education: vii, 1997.

[8] Jackson, D, Business graduate performance in oral communication skills and strategies for improvement, The International Journal of Management Education, 12, (1): 22-34, 2014.

[9] Bolton, T, GNVQ Core Skills in University Business Studies Curriculum, Colchester: Anglia Polytechnic University (working paper, unpublished, 1997.

[10] Andrews, J \& Higson, H, 2008 Graduate Employability, 'Soft Skills' Versus 'Hard' Business Knowledge: A European Study, 2008.

[11] McGann, K, IBEC Education and Skills Survey, 2010

[12] Irish Universities Association (IUA), Reform of 3rd Level and Creation of 4th Level Ireland-Securing Competitive Advantage in the 21st Century, IUA, 2005

[13] Higher Education Authority (HEA), Creating Ireland's Knowledge Society: proposals for Higher Education Reform-A Submission by the Higher Education Authority to the OECD Review of Higher Education in Ireland, 2004. 
[14] Commission of the European Communities, Communication from the Commission: The role of the universities in the Europe of knowledge, COM (2003) 58 Final, Brussels, 2003

[15] James, W P \& Margaret, L H, Education for Life and Work: Developing Transferable Knowledge and Skills in the 21st Century. Washington DC: The National Academies Press, 2012.

[16] Binkley, M., Erstad, O., Herman, J., Raizen, S., Ripley, M., Miller-Ricci, M., and Rumble M., Defining Twenty-First Century Skills. Chapter in Assessment and Teaching of 21st Century Skills. New York: Spinger, 2012.

[17] Byers, W, Promoting active learning through small group laboratory classes. University Chemistry Education, 6, 28-34, 2002.

[18] Kirschner, P A \& Meester, M A, The laboratory in higher science education: problems, premises and objectives. Higher Education, 17, 81-98, 1998.

[19] Sharpe, M R, Secondary school student's attitudes to practical work in school science. Thesis PhD. University of York Education, 2012.
[20] Zezekwa, N 2011 Students' attitudes towards advanced level physics practical Work. Journal of Education. 1 (2), 31-35, 2011.

[21] Brookhart, S M, How to assess higher order thinking skill in your classroom. Alexandria, Virginia: ASCD, 2010.

[22] Puccio, G. K, An analysis of an observational study of creaive problem solving for primary children. Thesis. State University College at Buffalo. Center for Studies in Creativity, 1994.

[23] Ellianawati dan B. Subali, Implementation model problem solving laboratory for increase quality practicum Basic Physics, Jurnal Pendidikan Fisika Indonesia, Vol 6, No 2, p.90-97, 2010.

[24] Heller, P \& Heller, K, Problem solving labs, in cooperative group problem solving in physics. Minnesota: Departement of Physics University of Minnesota, 1999.

[25] Peraturan Presiden Nomor 82012 tentang Kerangka Kualifikasi Nasional Indonesia. 